\title{
Doing Minority Justice Through Procedural Fairness: Face Veil Bans in Europe
}

\section{Saïla Ouald Chaib* and Eva Brems**}

We all move through our lives, a lot of the time, wrapped in a fog of our own selfish aims and desires, seeing other people as mere instruments of those desires. Kant thought, plausibly, that we need good principles to address this ubiquitous failing. But we need something else as well, the habitual cultivation of a displacement of mind, a curious, questioning, and receptive demeanor that says, in effect, "Here is another human being. I wonder what he (or she) is seeing and feeling right now." This curiosity needs to be fed by facts: for without correct historical and empirical information we can't possibly answer such a question. But it needs something more, a willingness to move out of the self and to enter another world. ${ }^{1}$

\begin{abstract}
The French and Belgian bans on face veils in public places have been subjected to strong substantive human rights critiques. This article takes a complementary approach, examining the bans from the perspective of procedural fairness. Indeed, the French and Belgian bans are extreme examples of legislative processes taking place above the heads of the people concerned, neglecting the ban's possible human rights impact. After exploring what the social psychology notion of procedural fairness entails for the judiciary and the legislator, especially in a multicultural context, this article details procedural fairness shortcomings with respect to the face veil ban in France and Belgium. Subsequently, the article sets out how the European Court of Human Rights might compensate for these shortcomings.
\end{abstract}

Key words: Face veil bans, Human Rights, Procedural Justice, Freedom of religion, European Court of Human Rights.

In the name of women's rights, public security and social cohesion, two European countries, France and Belgium, have enacted laws prohibiting face covering in the public space, generally known as 'burqa bans'. ${ }^{2}$ These bans have been strongly criticized as violations of religious freedom and

\footnotetext{
* PhD Candidate at the Human Rights Centre of Ghent University.

** Professor in Human Rights Law, 'Law and Gender' and 'Law and Islam' at Ghent University.

This contribution was made possible thanks to funding from the European Research Council for the project "Strengthening the European Court of Human Rights: More Accountability through Better Legal Reasoning".

${ }^{1}$ Nussbaum, Martha, The New Religious Intolerance, (Harvard University Press, 2012), 140.

${ }^{2}$ The French law prohibiting the conceilment of the face in the public space (Loi $\mathrm{n}^{\circ} 2010-1192 \mathrm{du} 11$ octobre 2010 interdisant la dissimulation du visage dans l'espace public) came into force on 11 April 2011. The Belgian law of 1 June 2011 instituting a prohibition on wearing clothing tha covers the face, or a large part of it" (Loi visant à interdire le port de tout vêtement cachant totalement ou de manière principale le visage) came into force on 13 July 2011.
} 
Published in Journal of Muslims in Europe 2 (2013) 1-26

discriminations on grounds of religion and sex. ${ }^{3}$ Complementing such substantive human rights critiques, this paper takes a different approach, examining the bans from the perspective of procedural fairness. Indeed, the French and Belgian bans are extreme examples of legislative processes taking place above the heads of the people concerned. Not only was the voice of the women concerned missing in the debates, even more striking was the fact that a discussion of the ban's human rights impact was nearly non-existent.

In a first section, we will refer to social psychology research to explain what procedural fairness encompasses and what it entails for both the judiciary and the legislator, particularly in a multicultural context. Next, we will demonstrate how the French and Belgian authorities have neglected procedural fairness at the domestic level. In the third section, we will argue how the European Court of Human Rights, if confronted with the subject matter, might restore procedural fairness.

\section{Procedural Fairness and Minority Justice}

Procedural fairness or procedural justice refers to the fairness of the procedures by which a decision is taken or by which an outcome is arrived at in a case. Social psychology research has shown that in their fairness assessment of authorities and the law, people tend to accord more importance to procedural fairness than to distributive justice. ${ }^{4}$ In other words, the way people are treated by judges and authorities is more relevant to them than the particular outcome in their case or the policy

\footnotetext{
${ }^{3}$ See also Brems, Eva, Vrielink, Jogchum and Ouald Chaib, Saïla, "Uncovering French and Belgian Face Covering Bans", Journal of Law, Religion and State. (Forthcoming)

${ }^{4}$ Tyler, Tom R., "Procedural Justice and the Courts", Court Review, 44(1/2) (2008), p.26; Tyler, Tom R., "What is procedural justice?: Criteria used by citizens to assess the fairness of legal procedures", Law and Society Review, 22 (1988), p. 121; Gangl, Amy, "Procedural Justice Theory and Evaluations of the Lawmaking Process", Political Behavior, 25, 2 (2003), p. 120 (with reference to Hibbing, John R, and Theiss-Morse, Elizabeth, "Process Preferences and American Politics: What the People Want Government to Be", The American Political Science Review 95(1) (2001), pp. 145-153.
} 
Published in Journal of Muslims in Europe 2 (2013) 1-26

decision taken. This does not mean however that the outcome is considered irrelevant. ${ }^{5}$ Procedural fairness and distributive justice should be seen as mutually strengthening approaches rather than substitutes. ${ }^{6}$

\subsection{Importance of Procedural Fairness}

Initially, procedural justice research focused on the question of compliance with the law. Tyler and his associates found that the legitimacy of an authority shapes compliance and that legitimacy is rooted in procedural fairness judgments. ${ }^{7}$ Hence, the first reason for authorities to accord particular importance to procedural fairness is maintaining their own legitimacy and that of the law. Central to the idea of legitimacy is the belief that "some decision made or rule created by [the] authorities is 'valid' in the sense that it is 'entitled to be obeyed' by virtue of who made the decision or how it is made".$^{8}$ As a consequence, procedural fairness also enhances cooperation with authorities. ${ }^{9}$ It can also be argued that when a human rights body such as the European Court of Human Rights is involved, the importance of procedural justice is even more important 'because it is part of the value system they represent' and because the legitimacy of human rights law is at stake. ${ }^{10}$

Moreover, it promotes social cohesion and individual well being. Research has consistently shown that "[p]eople ... value fair treatment by legal authorities because it communicates a message about their identities - that they are respected and valued members of society ${ }^{\prime 11}$ and that they can count on the authorities for protection, benevolence and consideration when needed. ${ }^{12}$

\footnotetext{
${ }^{5}$ Tyler, Tom R., "Governing amid diversity: Can fair decision-making procedures bridge competing public interests and values?", Law and Society Review, 28, (1994), p. 820-821.

${ }^{6}$ Brems, Eva and Lavrysen, Laurens, "Procedural Justice in Human Rights Adjudication: The European Court of Human Rights”, Human Rights Quarterly, 35 (2013), p. 182.

${ }^{7}$ Tyler, Tom R., Why People Obey The Law (Princeton University Press, 2006), 270.

8 Idem, 277.

${ }^{9}$ Idem, 271.

${ }^{10}$ Brems and Lavrysen "Procedural Justice in Human Rights Adjudication: The European Court of Human Rights", p. 185.

${ }^{11}$ Tyler, Tom, Huo, Yuen, Trust in the Law (New York: Russell Sage Foundation, 2002), p. 167.

${ }^{12}$ Tyler, Why People Obey The Law, p. 175-176.
} 
Although it follows from Tyler's research that procedural fairness is equally important to majority populations as to minorities ${ }^{13}$, there are several reasons to believe that procedural fairness is particularly crucial for minority justice.

Firstly, overcoming minority members' above-average distrust of authorities ${ }^{14}$ may require particular vigilance on procedural fairness. ${ }^{15}$ Secondly, perceptions of social standing in the society gain a special significance for minority members. When certain people, e.g. youth, minorities or people with disabilities are treated unfairly, authorities might be sending the signal that these groups are marginal in society. ${ }^{16}$ In contrast, by treating minority individuals fairly the authorities convey a message of inclusion among the valued members of society.

\subsection{Components of Procedural Fairness}

Tyler and others highlight four criteria, according to which people evaluate procedural fairness: participation, trustworthiness, neutrality and respect. ${ }^{17}$

Participation, frequently called 'voice', represents the need of people to be able to express their own perspective, regardless of whether or not their voice will have an impact. ${ }^{18}$ Valuing participation requires moreover that people feel that their views are genuinely considered. ${ }^{19}$ Judges can show this

\footnotetext{
${ }^{13}$ Tyler, Huo, Trust in the Law, p. 152; Burke, Kevin and Leben, Steve, "Procedural Fairness: A Key Ingredient in Public Satisfaction", White paper for the American Judges Association (2007), 18; Tyler, Tom R, "Public Trust and Confidence in Legal Authorities: What Do Majority and Minority Group Members Want from the Law and Legal Institutions?", Behavioral Sciences and the Law (2001), p. 217 (with references)

${ }^{14}$ Tyler, Why People Obey The Law, p. 270, Tyler, Huo, Trust in the Law, pp. 142-146; Tyler, "Public Trust and Confidence in Legal Authorities: What Do Majority and Minority Group Members Want from the Law and Legal Institutions?", p. 217; Levi, Margaret, Sacks, Audrey and Tyler, Tom, “Conceptualizing Legitimacy, Measuring Legitimating Beliefs", American Behavioral Scientist 53(3) (2009), p. 369.

${ }^{15}$ See also Ouald Chaib, Saïla, "Suku Phull v. France Rewritten from a Procedural Justice Perspective: Taking Religious Minorities Seriously" in Diversity and European Human Rights: Rewriting Judgments of the ECHR, Eva Brems (ed.) (Cambridge, Cambridge University Press, 2012), p. 221.

${ }^{16}$ Tyler, Why People Obey The Law, p. 176.

${ }^{17}$ See for example Tyler, "Procedural Justice and the Courts", 30.

${ }^{18} \mathrm{Ibid}$. and Burke and Leben, "Procedural Fairness: A Key Ingredient in Public Satisfaction”, p. 11-12.

${ }^{19}$ Tyler, Why People Obey The Law, p. 149 and 276.
} 
by referring to parties' arguments in the judgment and carefully examining the merits of the case. ${ }^{20}$ When people are confronted with an authority with which they have less direct contact, such as a legislator, direct voice is less important. ${ }^{21}$ Yet that does not make participation irrelevant. People still expect their interests to be taken into account. ${ }^{22}$ For minorities this might be of additional relevance since the "underrepresentation of a group in the legislature (...) may reduce the group members' sense of ownership, increase their sense of injustice and partiality in the determination of policy, and dampen their obedience to authority". ${ }^{23}$

Trustworthiness refers to authorities' intentions. They must be sincere and caring. ${ }^{24}$ The question at hand is whether authorities are making an effort to be fair $^{25}$ and people will evaluate whether they "are being honest and open about the basis for their actions; are trying to do what is right for everyone involved, and are acting [...] not out of personal prejudices" ${ }^{26}$

Neutrality requires judges to be honest and unbiased about the applicant and the case and to base their decision upon rules and on objective information about the case and on the arguments of the parties instead of personal assumptions. ${ }^{27}$ Neutrality requires also transparency about the way decisions are taken and how the rules are applied. ${ }^{28}$ It also involves consistency across people, over time and across cases. ${ }^{29}$ For lawmakers, neutrality requires that the interests of the whole population are taken into account. All views should be considered and no one view should be granted an obvious advantage in the policy debate..$^{30}$ It may be argued that particular caution should be paid to this when minorities are not represented in legislative bodies. Therefore, in our view, it is important

\footnotetext{
${ }^{20}$ Brems and Lavrysen "Procedural Justice in Human Rights Adjudication: The European Court of Human Rights", 186.

${ }^{21}$ Gangl, "Procedural Justice Theory and Evaluations of the Lawmaking Process", p. 136.

${ }^{22}$ Levi, Sacks and Tyler, "Conceptualizing Legitimacy, Measuring Legitimating Beliefs", p. 360.

${ }^{23}$ Ibid.

${ }^{24}$ Tyler, "Procedural Justice and the Courts", p. 31.

${ }^{25}$ Tyler, "What is procedural justice?: Criteria used by citizens to assess the fairness of legal procedures", p. 129 en Tyler, Why People Obey The Law, p. 164.

${ }^{26}$ Tyler, "Procedural Justice and the Courts", p. 30

${ }^{27}$ Ibid. and Tyler, Why People Obey The Law, p. 164.

${ }^{28}$ Tyler, "Procedural Justice and the Courts", p. 30 and Burke and Leben, "Procedural Fairness: A Key Ingredient in Public Satisfaction", p. 6.

${ }^{29}$ Tyler, "Procedural Justice and the Courts", p. 30 and Ouald Chaib, "Suku Phull v. France Rewritten from a Procedural Justice Perspective, p. 223.

${ }^{30}$ Gangl, "Procedural Justice Theory and Evaluations of the Lawmaking Process", p. 121.
} 
that lawmakers be sufficiently informed on minorities' interests and needs when enacting legislation that affects them. In fact, neutrality also requires accuracy: informed decisions based on accurate information. $^{31}$

The final criterion, respect means that people's human dignity is not infringed and that authorities treat them in a polite and respectful way. ${ }^{32}$ This criterion is particularly relevant for individuals' feeling of self-worth, as mentioned above. ${ }^{33}$

\section{Denial of Procedural Fairness at the Domestic Level}

The kick-off of the French 'burqa ban' process was a speech by President Nicolas Sarkozy on 22 June 2009, stating that face veils were not welcome in France, and that legislation was necessary "to protect women from being forced to cover their faces and to uphold France's secular values" ${ }^{34}$ The French Parliament subsequently initiated an inquiry into the issue, led by MP André Gerin. The 32 member Gerin Commission represented all parliamentary groups. It heard witnesses and experts, and sent out questionnaires to several French Embassies. Its January 2010 report concluded that the face veil constituted an infringement of the three principles constitutive of the French Republic: liberty, equality and brotherhood. The majority of the commission therefore recommended that Parliament adopt a resolution proclaiming this, as well as a law banning the face veil in public spaces. On 11 May Parliament unanimously adopted said resolution. ${ }^{35}$ This paved the way for the ban. In the

\footnotetext{
${ }^{31}$ Tyler, Tom R., "Governing amid diversity: Can fair decision-making procedures bridge competing public interests and values?", Law and Society Review, 28, (1994), p. 824.

${ }^{32}$ Burke and Leben, "Procedural Fairness: A Key Ingredient in Public Satisfaction", p;7; Tyler, Why People Obey The Law, p. 152; see also Nussbaum, The New Religious Intolerance, (Harvard University Press, 2012), p. 65. ${ }^{33}$ Idem, p. 129.

34 Gabizon, Cécilia, "Sarkozy : 'la burqa n'est pas la bienvenue"”, Le Figaro, 26 June 2009, http://www.lefigaro.fr/politique/2009/06/23/01002-20090623ARTFIG00055-sarkozy-la-burqa-n-est-pas-labienvenue-.php (Last consulted on 31/10/2012, our translation).

35 Résolution no. 2272 réaffirmant la prééminence des valeurs républicaines sur les pratiques communautaristes et condamnant le port du voile intégral comme contraire à ces valeurs, Assemblée nationale.
} 
Published in Journal of Muslims in Europe 2 (2013) 1-26

summer of $2010,{ }^{36}$ the bill passed in both houses of Parliament with an overwhelming majority, despite negative advice of the Council of State, which estimated that "no incontestable legal basis" could be provided for a general ban. ${ }^{37}$ The Constitutional Council however declared the ban to be constitutional in October 2010, with only a minor reservation for places of worship open to the public. $^{38}$

In Belgium, the 'burqa ban' debate took place at a time of severe political crisis. Shortly after the near-unanimous approval ${ }^{39}$ of a ban by the Chamber of Representatives, the government fell prematurely and Parliament was dissolved on 7 May 2010. As the Senate had 'evoked' ${ }^{40}$ the bill, this meant that the newly elected Parliament had to start over. While political negotiations for a new coalition government were going on for more than a year, the ban was adopted fast, without referral to the Council of State for advice. This time the Senate did not evolke the bill, which was approved by the Chamber of Representatives with an overwhelming majority ${ }^{41}$. In Belgium too, the law was unsuccesfully challenged before the Constitutional Court, also with a minor reservation for places of worship. $^{42}$

A closer look at the processes in both countries reveals serious shortcomings with respect to several procedural fairness requirements.

\subsection{Accuracy}

\footnotetext{
${ }^{36}$ In the lower house the bill received 335 ayes, only 1 nay, and 221 abstentions (13 July 2010). In the Senate there were 246 ayes, 1 nay, and 100 abstentions (14 September 2010).

37 "Etude relative aux possibilités juridiques d'interdiction du port du voile integral", Rapport Assemblée générale plénière du Conseil d’Etat, 25 March 2010.

${ }^{38}$ French Constitutional Council, 7 October 2010, no. 2010-613 DC.

${ }^{39}$ More specifically it concerned 136 ayes, 0 nays and 2 abstentions.

40 The majority of legislative proposals in Belgium are 'optionally bicameral'. Regarding such proposals, the governing principle is that the Chamber of Representatives has the authority to approve a bill autonomously but the Senate has the right to 'evoke' the approved bill and discuss it. This so-called 'right of evocation' must be invoked within a certain term and it requires a minimum number of members.

${ }^{41}$ In the plenary Chamber, there were 129 ayes, 1 nay and 2 abstentions.

42 Belgian Constitutional Court, 6 December 2012, no. 145/2012.
} 
Accuracy is an aspect of the neutrality of the law. ${ }^{43}$ This means simply that the law has to be based on information that is correct. In this respect, both the Belgian and French 'burqa ban' laws are seriously flawed. Several commentators have noted that in the legislative process, no evidence was adduced that would allow to identify the exact problem the law would remedy, nor to support the claim that the specific remedy - i.e. the ban- would be effective with respect to that problem. ${ }^{44}$ The Belgian and French legislators were rather well tuned in with majority sentiments vis-à-vis the face veil, yet they were working on erroneous assumptions concerning the profiles and experiences of women wearing the face veil. ${ }^{45}$ The central error is the assumption that all -or nearly all- women who wear the face veil are forced or pressured to do so. Since the adoption of the bans, empirical research based on interviews with face veil wearers in France ${ }^{46}$ and Belgium ${ }^{47}$ has shown that in fact the main profile is that of women choosing to wear the veil as a matter of an individual spiritual journey, generally against opposition of their family and in many cases of their partner as well. This is consistent with research in the Netherlands ${ }^{48}$ and Denmark, ${ }^{49}$ that was available at the time of

$43 \quad$ T. Tyler, Why People Obey the Law, p.119, referring to the criteria developed by G.S. Leventhal, "What should be done with equity theory?" in Social exchange: Advances in theory and research, Gergen, Greenberg and Weiss (eds.) (New York: Plenum), 1980, 27-55.

$44 \quad$ Leane, Geoffrey W.G., "Rights of ethnic Minorities in Liberal Democracies: Has France Gone too far in Banning Muslim Women from wearing the Burka?", HRQ 33 (2011), p.1053; Hunter-Henin, Myriam, "Why the French Don't Like the Burqa: Laïcité, national Identity and Religious Freedom", International and Comparative Law Quarterly 61(3) (2012), p. 613; Nanwani, Shaira, "The Burqa Ban: An Unreasonable Limitation on Religious Freedom or a Justifiable Restriction?", Emory International Law Review 25 (2011), p. 1464. Cf. on the

Netherlands: van Sasse van Ysselt, Paul, "Over het verbod op het dragen van een gezichtssluier en van andere gelaatsbedekkende kleding", Tijdschrift voor Religie, Recht en Beleid 2010 (1), p. 7.

$45 \quad$ For an extensive discussion of the erroneous assumptions of the Belgian legislator as confronted with empirical reality, see Brems, Eva, Janssens, Yaiza, Lecoyer, Kim, Ouald Chaib, Saïla, Vandersteen, Victoria and Vrielink, Jogchum, "The Belgian 'Burqa Ban' Confronted with Insider Realities”, in The Face Veil in Europe Inside and Out, Brems, Eva (ed.) (forthcoming).

$46 \quad$ Open Society Foundations, "Unveiling the Truth; Why 32 Muslim Women Wear the Full-Face Veil in France", 2011, at http://www.soros.org/publications/unveiling-truth-why-32-muslim-women-wear-full-faceveil-france.

Brems, Eva, Janssens, Yaiza, Lecoyer, Kim, Ouald Chaib, Saïla, Vandersteen, Victoria, "Wearing the Face Veil in Belgium; Views and Experiences of 27 Women Living in Belgium concerning the Islamic Full Face Veil and the Belgian Ban on Face Covering", 2012, at http://www.ugent.be/re/publiekrecht/en/research/humanrights/faceveil.pdf.

Moors, Annelies, “Gezichtssluiers; Draagsters en Debatten”, Amsterdam, 2009, at http://www.equality.nl/assets/e-

quality/dossiers/Moslimas/Onderzoek\%20Gezichtssluiers\%20draagsters\%20en\%20debatten.pdf. (Consulted on 31/10/2012)

49 "Rapport om brugen af niqab og burka", Institute of Cross-Cultural and Regional Studies, University of Copenhagen, 2009, at www.e-pages.dk/ku/322/. (Consulted on 31/10/2012). 
lawmaking. Moreover, an expert testified before the Gerin commission that the wearing of the face veil in France was a matter of 'religious hyper-individualism' in which women choose to submit to a religious rule. ${ }^{50}$ The finding that the assumption of coercion is wrong renders moot at least two of the arguments used by both legislators to justify the ban. The first is the argument based on women's rights. If women are not forced to wear the veil but instead freely choose to do so, the bans instead of liberating women, curtail their autonomy. Moreover they strengthen stereotypes about Muslim women's subordination. In both ways, the bans work against women's rights. The second is the argument about social integration. When donning the face veil is a well-considered choice, many women will not consider abandoning it as a first option when confronted with the ban. They prefer instead to continue wearing the veil yet avoid going out in public except by car. ${ }^{51}$ For these women, the bans reduce social integration. Moreover, empirical research also questions the relevance of the third argument in the parliamentary debates, which is based on security concerns. It appears in fact that face veil wearers are generally willing to lift their veils for identity checks, in many cases even to male security personnel..$^{52}$

The fact that the legislators literally had no idea what they were dealing with, ${ }^{53}$ thus had important consequences for the impact of the ban. Disregarding essential evidence in the course of lawmaking is highly problematic; it is even more so when it concerns legislation restricting fundamental rights. In Belgium, the disregard seems deliberate, as Parliament insisted on moving fast, and in that spirit rejected both a request for the hearing of experts who could have advanced evidence, and requests for an advice of the Council of State, who could have checked whether the proponents of the ban advanced sufficient evidence to support their arguments. In France however, the Gerin Commission

\footnotetext{
$50 \quad$ Gérin, André, “Rapport d'information fait en application de l'article 145 du règlement au nom de la mission d'information sur la pratique du port du voile intégral sur le territoire national", 26 January 2010, p. 469. Cf. also Amghar, Samir, “Le 'niqâb' pour s'affirmer?”, 2 January 2010, at http://www.cerasprojet.org/index.php?id=4196. (Consulted on 31/10/2012)

Brems et al., "Wearing the Face Veil in Belgium; Views and Experiences of 27 Women Living in Belgium concerning the Islamic Full Face Veil and the Belgian Ban on Face Covering". $52 \quad$ Ibid.

$53 \quad$ About the Netherlands: Witteveen, Willem, "Montesquieu en het boerkaverbod", 20 May 2010, at http://njblog.nl/2010/05/20/montesquieu-en-het-boerkaverbod/. (Last accessed on 31/10/2012)
} 
Published in Journal of Muslims in Europe 2 (2013) 1-26

auditioned 211 persons and produced a 658 page report. Yet the same flaws occurred. One of the auditioned experts suggests that an erroneous presentation of reality may have been brought in through the analyses of some of his colleagues, as they were set on an ideological reading of the face veil and on interpreting it as a sign of domination and alienation of Muslim women. ${ }^{54}$

Moreover neither the French Constitutional Council nor the Belgian Constitutional Court did anything to correct this flaw. ${ }^{55}$ Both had the power and the opportunity to require the government to advance evidence as to its correct assessment of the problem the legislation sought to address, and of the ban's likelihood to remedy that problem. Yet, the French Council chose to only reiterate the legislator's assumptions that the face veil could endanger public security and the minimal requirements of living together and that women wearing a face veil, "whether voluntarily or not" are in a situation of exclusion and inferiority that is manifestly incompatible with the constitutional principles of liberty and equality. ${ }^{56}$

The Belgian Constitutional Court did a slightly better job with regard to accuracy, acknowledging both that no security problem involving face covering occurred yet in Belgium ${ }^{57}$, and that the face veil can be a manifestation of a well-considered choice ${ }^{58}$. Nevertheless it accepted the ban as necessary for security reasons as well as for reasons of gender equality. With regard to the former, the Court argued that the State was allowed to "anticipate" potential risks. ${ }^{59}$ As to the gender argument, the Court stated that regardless of free choice, the principle of gender equality justifies a ban on religious manifestations that are not reconcilable with the principle of equality between men and women. ${ }^{60}$ Thus, although the Court does bring nuance to the legislator's general assumptions, these nuances do not affect the reasoning whatsoever. With regard to the social integration argument however, the

\footnotetext{
$54 \quad$ Amghar, Samir, "Niqab, quels sens pour celles qui le portent?”, Le Monde des Religions 40 (2010).

55 Davis, Britton, "Lifting the Veil: France's New Crusade", B.C.Int'l \& Comp.L.Rev. 34(1) (2011), p.139140.

${ }^{56}$ French Constitutional Council, 7 October 2010, no. 2010-613 DC, 4. ,

${ }^{57}$ Belgian Constitutional Council, 6 December 2012, no. 145/2012, B 20.2.

${ }^{58}$ Idem, B 23.

${ }^{59}$ Idem, B 20.3

${ }^{60}$ Idem, B 23.
} 
Published in Journal of Muslims in Europe 2 (2013) 1-26

Belgian Constitutional Court fully endorsed the role of speculator when stating that covering the face renders an essential element of a person's individuality invisible, making life in society impossible. ${ }^{61}$

\subsection{Neutrality/Sincerity/Transparence}

For lawmakers, the requirement of neutrality comes close to those of sincerity and transparence. It is about being clear on the purpose of the legislation, and seriously striving to best achieve that purpose. In the case of conflicting interests between different categories of people affected by the law, it is also about taking the interests of all categories equally seriously.

Both the French and Belgian laws ban face covering in general, even though the legal history and the accompanying discourse make clear that they target the Islamic face veil specifically. The neutral wording is intended chiefly to avoid legal challenges of discrimination on grounds of religion. Yet it goes at the expense of sincerity and transparence. Both the Belgian and French legislators have been accused of hypocrisy for disguising the real objective of the law. ${ }^{62}$ The legislators 'desire to 'appear impartial and reasonable ${ }^{63}$ extended to the parliamentary debates, where parliamentarians avoided as much as possible mentioning Islam. Following French president Sarkozy's statement in his speech to parliament in 2009 , that 'the burqa is not a sign of religion, it is a sign of subservience', politicians have gone out of their way to describe the face veil as a matter of culture, not religion. ${ }^{64}$

Furthermore, commentators of the French Gerin Commission and the ensuing legislative process have alleged bias in the selection of the persons to be auditioned ${ }^{65}$ as well as in the interpretation of

\footnotetext{
${ }^{61}$ Idem, B 21.

62 Delgrange, Xavier, “Quand la burqa passé à l'Ouest, la Belgique per-elle le Nord?”, in Quand la burqa passé à l'Ouest. Enjeux éthiques, politiques et juridiques, Roy, Olivier and Koussens, David (eds.) (Rennes: Presses universitaires de Rennes (Forthcoming, 2013), p. 35.; Hunter-Henin, "Why the French Don't Like the Burqa: Laïcité, national Identity and Religious Freedom", p. 617.

$63 \quad$ Winet, Evan D., "Face-Veil Bans and Anti-Mask Laws: State Interests and the Right to Cover the Face", Hastings Int'l \& Comp. L. Rev. 35 (2012), p. 244.

$64 \quad$ Cf. in the Netherlands, Moors, Annelies, "Minister Donner as Mufti: New developments in the Dutch 'burqa debates'”, September 2011, at http://religionresearch.org/martijn/2011/09/21/minister-donner-asmufti-new-developments-in-the-dutch-\%E2\%80\%98burqa-debates\%E2\%80\%99/. (Last accessed 31/10/2012) Krivenko, Ekaterina Yahyaoui, "The Islamic Veil and its Discontents: How do they Undermine Gender Equality", Religion and Human Rights 7 (2012), p. 20-21.
} 
the information from the auditions by the Commission. It was noted that the final report erased the plurality of reasons explaining the practice of the face veil that were advanced at the Commission's hearings. ${ }^{66}$ Moreover, it can be argued that parliamentarians interpreted the Gerin report in a selective and biased manner, as in addition to a ban, the report also proposed a number of positive measures related to sensitization, mediation, respect for diversity and the rejection of discrimination, none of which were taken up in the political work that followed the report. ${ }^{67}$

The French Council of State is not beyond criticism from the angle of neutrality. It was the Council that came up with the novel concept of 'non material public order', 'a minimum base of reciprocal requirements and guarantees that are essential to life in society and that... are so fundamental as to precondition the exercise of other liberties' ${ }^{68}$ Even though the Council of State advised against the use of this concept, it became one of the main foundations of the ban. Critics have argued that this concept, also labeled 'social public order' is far from neutral, as it allows 'to sweep away human rights whenever their manifestation is offensive to the majority of citizens' ${ }^{69}$

For courts, neutrality requires that judges act as "neutral, principled decision makers who make decisions based upon rules and not personal opinions." ${ }^{\prime 70}$ This relates to perceptions of independence and impartiality of the judge, as well as to the equal treatment of all parties. In that respect, the French Constitutional Council, acting as a court in controlling the constitutionality of legal texts, has a problem. The Council is composed of political notables, including leading "conservative politicians who had taken vocal and often controversial stances on anti-Muslim and anti-immigrant campaigns and who were unlikely to obstruct a government close to their leanings" ${ }^{71}$ By hardly motivating its approval of the face covering ban, the Council left itself "unprotected to the criticism that it is not

\footnotetext{
66 Mullally, Siobhan, "Civic Integration, Migrant Women and the Veil: at the Limits of Rights?", The Modern Law Review 74(1) (2011), p. 34.

67 Delgrange, “Quand la burqa passé à l’Ouest, la Belgique per-elle le Nord?”, p. 24

$68 \quad$ French Council of State, "Etude relative aux possibilités juridiques d'interdiction du port du voile integral", p. 26.

$69 \quad$ Hunter-Henin, "Why the French Don't Like the Burqa: Laïcité, national Identity and Religious Freedom", p. 621.

$70 \quad$ Tyler, "Procedural Justice and the Courts, p. 30.

71 Joppke, Christian, “Limits of Restricting Islam: The French Burqa Law of 2010", (conference paper) at http://rps.berkeley.edu/content/limits-restricting-islam-french-burqa-commission, p. 30.
} 
Published in Journal of Muslims in Europe 2 (2013) 1-26

much more than a semi-political organ" ${ }^{72}$ Similar reasoning has been applied to the Belgian Constitutional Court, half the bench of which are former politicians, making it unlikely that it would dare criticize a law adopted with near unanimity. ${ }^{73}$ Although the Belgian Constitutional judges motivated their decision more thoroughly, the reasoning remained one-sided giving quasi-absolute weight to the State's arguments instead of balancing the interests of all the parties. ${ }^{74}$

\subsection{Participation}

In the process of lawmaking, individuals cannot expect to be heard in person. ${ }^{75}$ Yet individuals belonging to a group that is directly affected/targeted by a law have a legitimate expectation that their side of the story is somehow on the table. Moreover, substantive participation requires some evidence that these people's views have been considered by the decision maker.

This is yet another procedural fairness component that has been seriously neglected by the French and Belgian lawmakers who banned the face veil. Empirical research in Belgium has shown that women wearing the face veil experience intense frustration at the fact that this political intervention in their lives took place without consulting them or researching their situation. ${ }^{76}$ Moreover, several suggested that if there had been a dialogue, a compromise could have been found, for example wearing a veil in a different colour than black to cause less offense, or taking alternative measures for easy identification..$^{77}$ It is indeed arguable that this is a matter in which dialogue might lead the way

\footnotetext{
72 Van der Schyff, Gerhard and Overbeeke, Adriaan, "Exercising religious freedom in the public space: a comparative and European Convention analysis of general burqa bans", E.C.I. Review 7(3) (2011), p. 428.

73 Delgrange, Xavier, “La loi "anti-burqa" comme symptom", Politique-Revue des débats 74 (2012), p. 47.

${ }^{74}$ See supra and see also Ouald Chaib, Saïla, Belgian Constitutional Court says Ban on Face Coverings does not violate Human Rights, 14 December 2012, at http://strasbourgobservers.com/2012/12/14/belgianconstitutional-court-ban-on-face-coverings-does-not-violate-human-rights/. (Last accessed 25 January 2013) Even though the small numbers, in particular in Belgium, would have made that possible. See (on the Netherlands), Witteveen, "Montesquieu en het boerkaverbod". On the local level, where bans had been enacted in Belgium before the nationwide ban, individual contact seems a logical approach, as the localities concerned usually counted only a handful of face veils.

$76 \quad$ Brems et al., "Wearing the Face Veil in Belgium; Views and Experiences of 27 Women Living in Belgium concerning the Islamic Full Face Veil and the Belgian Ban on Face Covering". $77 \quad$ Ibid.
} 
to the best solution for all; or that at least dialogue should have been tried before resorting to the criminal law. ${ }^{78}$

Yet as shown above, the lawmakers were not really interested in information from the perspective of the face veil wearers. During the massive information gathering effort that was the French Gerin Commission, the idea of talking to a woman who wears the face veil came as an afterthought. Kenza Drider, the only face veil wearer who was heard by the Commission, states that she had written several letters to Mr. Gerin asking to appear before the Commission, and that she had to mobilize her media contacts in order to succeed. During her hearing, summarized in ten lines in the 658 page report, she had to unveil her face. ${ }^{79}$ Moreover, the Gerin report starts with an 'avant-propos', in which a member of the commission relates the one encounter he had with a (French) woman wearing the face veil, which was on a professional trip to Syria. According to the text the woman approached him because she wanted to explain the meaning of her face veil. The melodramatic text describes the scene in much detail and concludes that "the eyes of Farah from Marseille" were a source of motivation for the commissioners. Yet it remains mute on the content of her message. ${ }^{80}$ This is symptomatic of the whole report, and by extension of the entire lawmaking process that took place: the perspective of the women concerned was systematically shoved off the table. ${ }^{81}$ This is all the more remarkable given the fact that both Belgium and France have a strong tradition of consulting with target groups in the run-up to lawmaking. ${ }^{82}$ The derogation from democratic custom in this specific case cannot go unnoticed, neither by the women themselves, nor by the population at large.

\footnotetext{
$78 \quad$ van Sasse van Ysselt, “Over het verbod op het dragen van een gezichtssluier en van andere gelaatsbedekkende kleding”, p.7.

79 Open Society Foundations, "Unveiling the Truth; Why 32 Muslim Women Wear the Full-Face Veil in France", 2011, p.20.

80 Gérin, "Rapport d'information fait en application de l'article 145 du règlement au nom de la mission d'information sur la pratique du port du voile intégral sur le territoire national", p. 15-16; See Krivenko, "The Islamic Veil and its Discontents: How do they Undermine Gender Equality", p. 21. Hennette-Vauchez, Stéphanie, "La burqa, la femme et l'Etat", Raison Publique (2010) at http://www.raison-publique.fr/article317.html. (Last accessed: 31/10/2012) Cf. (on the Netherlands) Witteveen, "Montesquieu en het boerkaverbod".
} 


\subsection{Respect}

Treating people with respect means taking them and their concerns seriously, and treating them as valued members of society. ${ }^{83}$ Under this heading, at least three issues are cause of concern in the face veil banning process.

The first has been called "a neo-colonial form of paternalism". ${ }^{84}$ The Belgian and French legislators claim to want to liberate women wearing a face veil, yet they are not interested in the viewpoints of these women. They pretend to know better than them why they wear what they wear. ${ }^{85}$ Throughout their discourse, they picture these women as submitted, dependent creatures. The legislators thus deny these women autonomy. Moreover, the legislators dwell extensively on how the majority in society experience the encounter of a face veil or even the idea of a face veil, yet show no interest in knowing how women who wear it experience their encounters with others. They thus ignore the women behind the veil, denying them humanity.

In the second place, the legislators do not take seriously the infringement they are creating into a fundamental right, i.e. the freedom to express one's religion. They consistently downplay the religious factor, despite the fact that for most women who wear the face veil, the central reason for doing so is a deep religious commitment. Even more importantly, they go lightly about tampering with a fundamental right. This is evidenced most clearly in the blatant ignoring of the advice of the French Council of State, and in the refusal to consult the Belgian Council of State. In addition to the legislator, the French Constitutional Council did not appear to take religious freedom seriously. It needed only one sentence to conclude that the face veil ban did not violate religious freedom:

\footnotetext{
$83 \quad$ Brems and Lavrysen "Procedural Justice in Human Rights Adjudication: The European Court of Human Rights", p. 181.

84 Hennette-Vauchez, "La burqa, la femme et l'Etat",

85 Leane, "Rights of ethnic Minorities in Liberal Democracies: Has France Gone too far in Banning Muslim Women from wearing the Burka?", p. 1054.
} 
Published in Journal of Muslims in Europe 2 (2013) 1-26

Taking into account the objectives he stated for himself as well as the nature of the sanction in case of breach of the rule, the legislator adopted provisions that guarantee a conciliation of the protection of public order and the protection of constitutional rights that is not manifestly disproportionate. $^{86}$

Even with the finest legal scalpel, it is hard to detect any reasoning or justification in these lines. This is the more striking, given the fact that the Council of State had earlier come to the opposite conclusion in an extensively motivated advice. The Constitutional Council did not even bother to brush the Council of State's arguments aside. Moreover, it adds insult to injury when it stipulates an exception to the ban: in order not to violate religious freedom, the French ban should not apply in places of worship that are open to the public. ${ }^{87}$ As this statement is likewise unmotivated, we cannot know whether the Council is deliberately reinterpreting a religious dress practice to make it into part of a mosque ritual, nor on what basis it claims the power to do so. The same holds for the Belgian Constitutional Court, which stipulated the same reservation in its judgment. Thirdly, the discourse surrounding the introduction of the bans shows a strong tendency of 'othering ${ }^{\prime 88}$. Women who wear a face veil are not portrayed as members of the same society as those who encounter them on the street, and those who decide to ban the veil. Nicolas Sarkozy set the tone when he announced that "the burqa will not be welcome on the French territory" (cf. supra). This speech has been analysed as an example of ethnonationalism: by labeling the face veil as foreign to French identity, there is no acknowledgement of the possibilities of a hybrid or multilayered identity, that would at the same time be profoundly French and profoundly Islamic. ${ }^{89}$ Moreover, Sarkozy's 'colonial gaze' at the face veil mobilizes the French around self-proclaimed French values while excluding the face veil wearers from both those values and the idea of Frenchness. ${ }^{90}$ Mullally noted that the Gerin Commission's

\footnotetext{
86 French Constitutional Council, 7 October 2010, no. 2010-613 DC, para 5. Our translation.

$87 \quad$ lbid.

88 On the 'otherization' of the face veil, see Chakraborti, Neil and Zempi, Irene "The veil under attack: Gendered dimensions of Islamophobic victimization", International Review of Victimology 18(3) (2012), 8. 
Published in Journal of Muslims in Europe 2 (2013) 1-26

presentation of its proposals as 'un accord républicain' clearly reflects "the desire to reinforce and bolster a collective sense of national identity, designed to define the terms of belonging." ${ }^{191}$ It deliberately targets those who symbolize otherness. Stigmatization, if not intentional, is at best accepted as collateral damage. ${ }^{92}$ The main purpose of the ban seems to be "to reassure public opinion that the political class is ready to stand up for 'our' values in the face of 'foreign' threats to 'our way of life'."'93

\subsection{Trust/caring}

The criterion of trust relates to the feeling among those affected by the law, that those who are making the law sincerely strive for justice. ${ }^{94}$ It is about the lawmakers showing to the people that they care. From this angle as well, the French and Belgian face veil bans are very problematic.

To the extent that the lawmakers in the face veil banning process show caring, it is caring about the majority population, for whom the face veil may engender feelings of insecurity, who dislike the sight of a face veil on the street, and who see the face veil as a symbol denying women's rights. The arguments advanced by both parliaments to ban the veil - women's rights, security, and social cohesion - make sense only from the (subjective) perspective of those who do not wear the face veil. As argued above, for the face veil wearers the bans have reduced women's rights, social integration and security. This lack of caring for the women concerned is most flagrant in the Belgian law, as - different from the French law - it does not include a stipulation against forcing a person to cover her face. While the authors of the ban were assuming that women wearing the face veil are

\footnotetext{
91 Mullally, “Civic Integration, Migrant Women and the Veil: at the Limits of Rights?”, p. 32

92 Nanwani, "The Burqa Ban: An Unreasonable Limitation on Religious Freedom or a Justifiable Restriction?", p.1447.

93 Laborde, Cécile, "State Paternalism and Religious Dress", International Journal of Constitutional Law 10(2) (2012), p.13.

94 Tyler, "What is procedural justice?: Criteria used by citizens to assess the fairness of legal procedures", p. 129.
} 
Published in Journal of Muslims in Europe 2 (2013) 1-26

coerced to do so, they apparently did not care enough about these women to punish the perpetrators. Manifestly the only problems the lawmakers cared about are those of the majority population.

An even more cynical interpretation is one that does not see any evidence of sincere caring by the lawmakers, except for their own electoral gain. Such is the suggestion among commentators who point at the fact that the bans enjoyed wide popular support, and that those supporting them politically would surf to similar popularity on waves of populism and islamophobia. ${ }^{95}$

At a more institutional level, the refusal of the Belgian lawmakers to hear experts or consult the Council of State, or the anti-discrimination watchdog, ${ }^{96}$ or even to seriously engage with any arguments against the ban, ${ }^{97}$ can be seen as evidence of lack of caring, in the sense that the focus on getting a ban voted, left no room for even the most common efforts aimed at doing things in a proper way. It was quite clear that the parliamentarians did not want to have to deal with criticism. One of the main proponents of the ban explicitly stated that the reason for avoiding the Council of State was the fear that it might find inconsistencies with fundamental rights. In other words, in their hurry to get the ban voted, politicians did not even care about fundamental rights. ${ }^{98}$

In France, the Council of State was consulted, yet the picture does not look any rosier. The Council crushed the proposed ban on grounds of incompatibility with fundamental rights. Similarly, the legal experts heard by the Gerin commission had warned that a general ban would be highly problematic. ${ }^{99}$ In an 'unprecedented defiance of concerted legal opinion' ${ }^{100}$ however, the French parliament ignored these objections, and several MPs engaged in public court-bashing against the

\footnotetext{
95 Hammarberg, Thomas, "Human Rights in Europe: no grounds for complacency", Council of Europe Publishing (2011), 41; Joppke, "Limits of Restricting Islam: The French Burqa Law of 2010", p. 28; Leane, "Rights of ethnic Minorities in Liberal Democracies: Has France Gone too far in Banning Muslim Women from wearing the Burka?", p. 1060; Van der Schyff and Overbeeke, "Exercising religious freedom in the public space: a comparative and European Convention analysis of general burqa bans", p. 15. 
Published in Journal of Muslims in Europe 2 (2013) 1-26

Council of State, ${ }^{101}$ signaling that if they cared about anything, it was not the rule of law or fundamental rights.

\section{Doing Procedural Minority Justice in Strasbourg}

As was to be expected, an application challenging the French face veil ban was brought before the European Court of Human rights. ${ }^{102}$ This is an opportunity for the Court to set the standard on procedural justice as well as substantive justice. In the analysis below we will explore how the Court could potentially realize the former.

\subsection{Assessing Domestic Procedural Fairness}

Throughout its case-law, the European Court of Human Rights regularly acts as a watchdog of domestic procedural fairness. In this respect it has evaluated decision making processes by domestic courts, administrations and lawmakers. It is noteworthy that the Court has paid attention to this in cases involving the rights of members of ethnic or religious minorities, even when it exercised only light scrutiny.

In particular, in cases involving article 8 - the provision that protects a minority lifestyle, ${ }^{103}$ as well as dealing with numerous issues of specific relevance for minorities, such as housing ${ }^{104}$ and registration of ethnic identity ${ }^{105}$ - the Court has regularly stated that "the decision-making process leading to measures of interference must be fair and such as to afford due respect for the interests of the

\footnotetext{
$101 \quad$ Idem, 28.

102 ECtHR, S.A.S v. France, application number (43835/11)

103 ECtHR (GC), Chapman v. UK, 18 January 2001, para. 73.

$104 \quad$ Ibid

105 ECtHR, Ciubotaru v. Moldova, 27 April 2010, para. 51.
} 
individual as safeguarded by Article 8." ${ }^{106}$ Moreover, the Court emphasized the minority component in its famous dictum in Chapman, a case concerning a Gypsy's right to live in a caravan on her land: "the vulnerable position of Gypsies as a minority means that some special consideration should be given to their needs and their different lifestyle both in the relevant regulatory planning framework and in reaching decisions in particular cases". ${ }^{107} \mathrm{~A}$ fine example of this, is the case of Noack $v$ Germany, ${ }^{108}$ concerning the collective transfer of the - mostly minority - inhabitants of a village to allow for mining expansion. The Court found the complaint manifestly ill-founded, basing its decision mostly on the elaborate procedures at the domestic level. The Court noted in particular that the process "lasted several years and that the distinctive feature of that process was the wide debate that took place in the Parliament of the Land of Brandenburg and among the other leading figures in public life regarding the choice between three alternative lignite-mining projects." ${ }^{109}$ It also drew attention to the due consideration of minority concerns during the process: "As regards protection of the rights of the Sorbian minority, the Court notes that ... the Constitutional Court of the Land of Brandenburg carefully examined whether the legislature had understood the scope of Article $25 \S 1$ of the Constitution of the Land of Brandenburg, which protects the rights of the Sorbs, whether it had duly weighed the right it enshrined against other fundamental rights and whether the result was not disproportionate."110

Under article 9 - protecting religious freedom - the Court, in its famous Grand Chamber case of Leyla Şahin v. Turkey, examined the way in which the Turkish headscarf ban for university students was introduced. In particular, it noted that the university authorities explained the reasons behind the ban to the students, ${ }^{111}$ and that "the process whereby the regulations ....were implemented took several years and was accompanied by a wide debate within Turkish society and the teaching

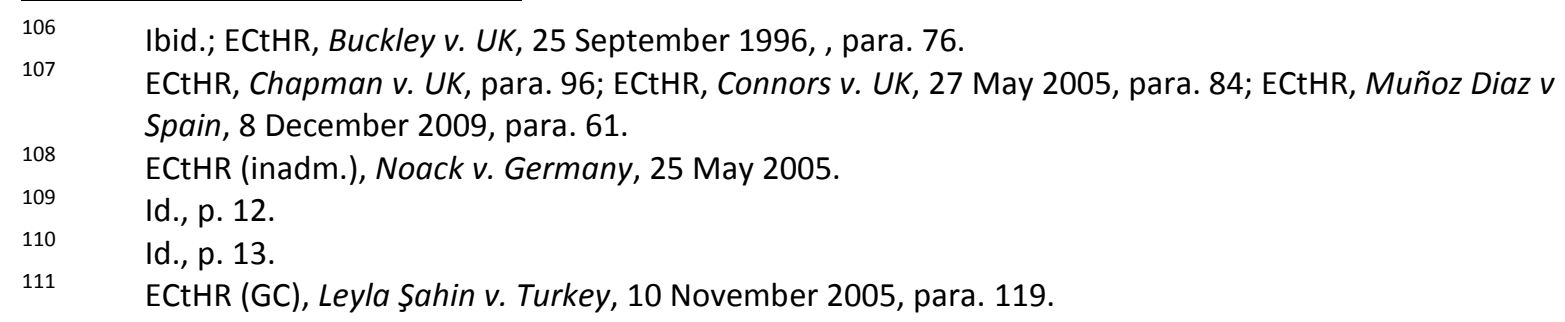


Published in Journal of Muslims in Europe 2 (2013) 1-26

profession ... It is quite clear that throughout that decision-making process the university authorities sought to adapt to the evolving situation in a way that would not bar access to the university to students wearing the veil, through continued dialogue with those concerned". ${ }^{112}$ Hence, the broad margin the Court left to national authorities to decide whether or not to ban headscarves in school, was to some extent compensated by a control of the domestic process. However, this type of procedural fairness assessment is far from systematic in the European Court's case-law.

Following Brems and Lavrysen, ${ }^{113}$ it is submitted that the control by the European Court of Human Rights should always include an appreciation of the extent to which procedural fairness has been done at the domestic level. Serious shortcomings of procedural fairness in cases involving Convention rights should systematically lead to the finding of a violation. Smaller shortcomings should be put in the balance with the other elements in the overall assessment of whether an infringement constitutes a violation. Moreover, the degree of scrutiny exercised by the Court could be linked to procedural fairness criteria, in the sense that light scrutiny - granting a wide 'margin of appreciation' to domestic authorities - would not be applied in case of procedural fairness flaws. Moreover, in cases involving minority rights, the procedural fairness check should include due attention paid to minority concerns.

Dealing with the French and/or Belgian face veil banning processes, the European Court of Human Rights would therefore be expected to point out the numerous and very serious procedural fairness shortcomings, and remind the states parties of proper practice. Moreover, it would have to exercise strict scrutiny at the European level so as to compensate for the absence of domestic procedural fairness.

\subsection{Doing it Right at the European Level}

\footnotetext{
112 Id., para. 120.

113 Brems and Lavrysen "Procedural Justice in Human Rights Adjudication: The European Court of Human Rights", p. 189.
} 
Published in Journal of Muslims in Europe 2 (2013) 1-26

In addition to setting the standard on domestic procedural fairness, we submit that the Court in its own work should strive for best practice in this field. This would both strengthen its credibility when criticizing domestic shortcomings and offer states parties concrete examples of procedural fairness in legal reasoning. Moreover, from applicants' perspective, fair treatment by this highest body in the hierarchy of law can offer some compensation for procedural unfairness suffered in earlier stages.

\section{a) Recognizing the Applicant}

The issue of voice is crucial for the European Court's treatment of the face veil case. As it examines the case from the starting point of the fundamental right at stake, the right holder's perspective comes natural to the Court. Throughout its reasoning, the Court should take care to present sufficient and accurate information on her experiences and to accurately present her arguments. While the applicant's perspective is centerpiece, information on the experiences of other face veil wearers provides a relevant contextualization.

Assuming that the applicant in SAS v. France corresponds to the 'standard profile' of face veil wearers in France, it is to be expected that her religious conviction is a crucial aspect of the insider perspective. ${ }^{114}$ The way a conviction is experienced and the importance accorded to it is subjective. Outsiders may not understand why a Sikh objects to removing his turban at a security check or why it might not be evident for a Muslim girl to remove her headscarf during sports classes. Similarly, outsiders may not understand why a woman decides to cover her face when appearing in public. In determining whether or not such behaviour falls under the European Convention, it is however the insider perspective that counts. It is not for the Court to determine what a religion prescribes or does not prescribe. ${ }^{115}$ Only the applicant-believer can autonomously decide this for herself. In most of its

\footnotetext{
${ }^{114}$ This can be derived from the facts of the case communicated to the state. ECtHR, S.A.S v. France, application number (43835/11), p.1.

${ }^{115}$ Martinez-Torron, Javier, "The (Un)protection of Individual Religious Identity in the Strasbourg Case Law", Ox. J Law Religion (2012), pp. 13-14; Evans, Carolyn, Freedom of Religion under the European Convention on Human Rights (Oxford: 2001), pp. 120-124.)
} 
case law, the Court has adopted a correct approach to this matter: the relevant question is whether the applicant finds a particular practice important in the context of her religion or belief. ${ }^{116}$

The ECtHR recently clarified in Eweida e.o. v. the UK that "the existence of a sufficiently close and direct nexus between the act and the underlying belief must be determined on the facts of each case. In particular, there is no requirement on the applicant to establish that he or she acted in fulfilment of a duty mandated by the religion in question". ${ }^{117}$ Accordingly, the autonomy of the believer implies also that it does not matter whether the religious dictate she wants to follow consists of a minority view within her religious group. ${ }^{118}$

Additionally, in light of the neutrality principle, the Court must refrain from making biased or generalizing statements about the applicant's religious conviction or practice. In the past, the Court has made a number of problematic statements such as "the rites and rituals of many religions may harm believers' well-being, such as, for example, the practice of fasting, which is particularly long and strict in Orthodox Christianity, or circumcision practiced on Jewish or Muslim male babies"119 or "wearing the Islamic headscarf could not easily be reconciled with the message of tolerance, respect for others and, above all, equality and non-discrimination that all teachers in a democratic society should convey to their pupils"120. Such statements in fact contradict the ruling that

" $(T)$ the right to freedom of religion as guaranteed under the Convention excludes any discretion on the part of the State to determine whether religious beliefs or the means used to express such beliefs are legitimate."121 122

\footnotetext{
${ }^{116}$ Rorive, Isabelle, "Religious Symbols in the Public Space: In search of a European Answer", Cardozo L. Rev. (2008-2009), p. 2674.

${ }^{117}$ ECtHR, Eweida and others v. UK, 15 January 2013, par. 82.

${ }^{118}$ Cf. Nussbaum, Martha, The New Religious Intolerance, p. 79.

${ }^{119}$ ECtHR, Jehovah's Witnesses of Moscow v. Russia, 10 June 2010, para. 144.

${ }^{120}$ ECtHR, Dahlab v. Switzerland, 15 February 2001; reiterated in Leyla Şahin v. Turkey, 10 November 2005, para. 111

${ }^{121}$ ECtHR, Manoussakis v. Greece, 26 September 1996, para. 47

${ }^{122}$ Martinez-Torron, "The (Un)protection of Individual Religious Identity in the Strasbourg Case Law", p. 25.
} 
In addition, such statements are stigmatizing ${ }^{123}$ and disrespect the plurality of meanings a certain religious expression can have ${ }^{124}$ as well as individual autonomy to choose what meaning to attach to a certain religious expression. ${ }^{125}$ Instead of taking part in the political debate about the meaning society imposes on the face veil the Court has with SAS v. France the opportunity to break the circle of prejudice and return to the essence of the issue at stake, namely the rights of the women concerned and their right to freedom of religion in particular. ${ }^{126}$

\section{b) Recognizing the Weight of the Applicant's Right}

In the domestic debates surrounding the face veil bans the impact of the bans on freedom of religion was hardly put on the table. It is the Court's task to redress procedural justice by considering the voice of all parties and by genuinely weighing the arguments against each other as prescribed by the second paragraph of article $9 \mathrm{ECHR} .{ }^{127}$ Procedural fairness requires moreover that this balancing exercise is done in a transparent manner, clarifying the weight given to each argument, as well as the underlying reason. Unfortunately the Court's adjudication in article 9 cases has often lacked clarity and consistency, in contrast with its case law under other provisions, such as freedom of expression. ${ }^{128}$ From a procedural fairness perspective, the Court should be careful not to create the impression that some rights are more valued than others. ${ }^{129}$ Although the Court describes in its case law the freedom of religion as "one of the most vital elements that go to make up the identity of

\footnotetext{
${ }^{123}$ Martinez-Torron, Javier, "Limitations on Religious Freedom in the Case Law of the European Court of Human Rights", Emory Int'l L. Rev. 19 (2005), p. 607.

${ }^{124}$ Grillo, Ralph and Shah, Prakash, "Reasons to Ban? The Anti-Burqa Movement in Western Europe", (2012) to be found at http://www.mmg.mpg.de/publications/working-papers/2012/wp-12-05/, p.31.

${ }^{125}$ Leane, "Rights of ethnic Minorities in Liberal Democracies: Has France Gone too far in Banning Muslim Women from wearing the Burka?", p. 1054; Krivenko, "The Islamic Veil and its Discontents: How do they Undermine Gender Equality", p. 19; Evans, Malcolm, Manual on the Wearing of Religious Symbols in Public Areas, (Strasbourg: Council of Europe Publishing, 2009), p. 44.

${ }^{126}$ Krivenko, "The Islamic Veil and its Discontents: How do they Undermine Gender Equality", p. 27.

${ }^{127}$ Lewis, Tom, "What not to wear: Religious rights, the European Court, and the margin of appreciation", ICLQ, vol 56 (2007), p.414.

${ }^{128}$ See for a comparative study on case law concerning religion in the workplace: Ouald Chaib, Sailla, "Religious Accommodation in the Workplace: Improving the Legal Reasoning of the European Court of Human Rights" in $A$ Test of Faith? Religious Diversity and Accommodation in the European Workplace, Katayoun Alidade, MarieClaire Foblets and Jogchum Vrielink (eds.)(Ashgate, 2012), pp33-58.

${ }^{129}$ Ouald Chaib, "Suku Phull v. France Rewritten from a Procedural Justice Perspective, p. 224; Lewis, "What not to wear: Religious rights, the European Court, and the margin of appreciation", p. 396.
} 
believers and their conception of life", ${ }^{130}$ in practice, the reasoning adopted in freedom of religion cases often shows a less understanding approach, especially when the individual aspect of the right is concerned. ${ }^{131}$ The Court's case law in the headscarf cases is well known for its one-sided approach, heavily relying on principles put forward by the State such as secularism and neutrality. ${ }^{132}$ But also in other cases concerning religious accommodation claims the Court has often shown a lack of understanding of the importance of religious claims for applicants in a particular situation. ${ }^{133}$ In Francesco Sessa v. Italy ${ }^{134}$ for example, the Court stated that a lawyer complaining about the scheduling of a hearing on a Jewish holiday, should arrange for replacement by a colleague if his religious and professional duties enter into conflict. ${ }^{135}$ It did not seriously consider the possibility that the organization of the judicial system might accommodate respect for his religious duties. In other cases, such as the cases concerning security measures in public buildings - requiring taking off religious dress -, the Court simply refers to the importance of security measures, omitting to examine the necessity of the measure for security. ${ }^{136}$ This insensitive approach towards religious claims should be avoided by carefully considering the concerns of the applicant and by genuinely and thoroughly balancing the interests at stake. Good practices can be found in the cases, rare in their kind, of Jakobski v. Poland ${ }^{137}$ and Ahmet Arslan v. Turkey ${ }^{138}$ and the recent case of Eweida and others v. the $U K^{139}$.

\section{c) Recognizing the Applicant's Minority Position}

\footnotetext{
${ }^{130}$ ECtHR, Kokkinakis v. Greece, 25 May 1993, para.31

${ }^{131}$ Martinez-Torron, Javier, "The (Un)protection of Individual Religious Identity in the Strasbourg Case Law", Ox. J Law Religion (2012), p.2.

${ }^{132}$ See for example Rorive, Isabelle, "Religious Symbols in the Public Space: In search of a European Answer", Cardozo L. Rev. (2008-2009) and Lewis, "What not to wear: Religious rights, the European Court, and the margin of appreciation".

${ }^{133}$ Cf. Ferrari, Silvio, "The Strasbourg Court and Article 9 of the European Convention of Human Rights: A Quantitative Analysis of the Case Law" in The Lautsi Papers: Multidisciplinary Reflections on Religious Symbols in the Public School Classroom, Temperman, Jeroen (ed.) (Martinus Nijhoff: 2012) p. 23 and Martinez-Torron, "The (Un)protection of Individual Religious Identity in the Strasbourg Case Law", p.6.

${ }^{134}$ ECtHR, Francesco Sessa v. Italy, 3 April 2012.

${ }^{135}$ ECtHR, Francesco Sessa v. Italy, para 37.

${ }^{136}$ See e.g. ECtHR, Phull v. France, 11 January 2005 and ECtHR, El Morsli v. France, 4 March 2008.

${ }^{137}$ ECtHR, Jakóbski v. Poland, 7 December 2010

${ }^{138}$ ECtHR, Ahmet Arslan and others v. Turkey, 23 February, 2012

${ }^{139}$ ECtHR, Eweida and others v. UK. (In particular in the case of the first applicant)
} 
As argued above, procedural fairness is particularly important when a minority is involved. That authorities should make an extra effort to keep confidence of minorities, was acknowledged by the Strasbourg Court in a recent case concerning racist violence towards Roma. ${ }^{140}$ When the Court examines legislation interfering with minority rights, it has an important corrective function of "protecting the rights of minority members against abuses of the majority rule by the dominant group." ${ }^{141}$ Indeed, there is always a risk that "law-making is done on the basis of dominant assumptions about minority cultures and their members' views, with the minority being treated as a silent interlocutor". ${ }^{142}$ When it comes to the face veil ban, the Court cannot overlook the fact that the discussion concerned a minority that was silenced in the debates. ${ }^{143}$ Moreover, face veiling women are in a particular vulnerable position since they consist of a small minority within the minority group of Muslims who are not necessarily supportive towards them. ${ }^{144}$

Some authors argue that the debates surrounding the face veil bans were so heated, because women wearing a face veil represent the Islam Europe does not want to see. ${ }^{145}$ It cannot be denied that the face veil bans are rooted in an anti-Islamic climate in Europe, and that this legislation even risks reinforcing the existing tensions. This has been extensively documented amongst others by Amnesty International, ${ }^{146}$ by the former Council of Europe Commissioner for human rights Thomas Hammarberg, ${ }^{147}$ by the European monitoring Centre on racism and Xenophobia, ${ }^{148}$ and by the

\footnotetext{
${ }^{140}$ ECtHR, Koky and Others v. Slovakia, 12 June 2012, para. 239.

${ }^{141}$ Brems and Lavrysen "Procedural Justice in Human Rights Adjudication: The European Court of Human Rights", (forthcoming).

${ }^{142}$ Grillo and Shah, "Reasons to Ban? The Anti-Burqa Movement in Western Europe", p. 28. This can be illustrated with the name of the campaign issued after the enactment of the ban: "La République se vit à visage découvert" meaning "The Republic is lived with uncovered face": http://www.gouvernement.fr/gouvernement/la-republique-se-vit-a-visage-decouvert

${ }^{143}$ See supra.

${ }^{144}$ Some women reported that they experienced aggression also from Muslims: http://www.ugent.be/re/publiekrecht/en/research/human-rights/faceveil.pdf, p. 19.

${ }^{145}$ Grillo and Shah, "Reasons to Ban? The Anti-Burqa Movement in Western Europe", p. 23.

${ }^{146}$ Choice and Prejudice; Discrimination against Muslims in Europe, Amnesty International 2012, http://www.amnesty.org/en/library/asset/EUR01/001/2012/en/85bd6054-5273-4765-938559e58078678e/eur010012012en.pdf

${ }^{147}$ Hammarberg, Thomas, "Human Rights in Europe: no grounds for complacency” ,, Council of Europe Publishing (2011), p.36.

148 "Muslims in the European Union: Discrimination and Islamophobia", EUMC 2006: http://fra.europa.eu/fraWebsite/attachments/Manifestations EN.pdf
} 
Published in Journal of Muslims in Europe 2 (2013) 1-26

Organization of the Islamic Conference. ${ }^{149}$ Also, the Parliamentary Assembly of the Council of Europe issued a resolution on "Islam, Islamism and Islamophobia in Europe" in which the face veil bans were discussed as well. ${ }^{150}$ In the recommendation with the same name, the Assembly called on member states not to establish a general ban of full veiling. ${ }^{151}$ The Court should recognize this "sensitive nature of the situation"152 in which hostility and discrimination towards Muslims is on the rise in many European countries. ${ }^{153}$

All these factors point at the particular vulnerable position of women wearing the face veil in France. In addition to close attention to neutrality and balancing in the Court's reasoning, they mandate specific care with respect to its discourse. Respect should characterize the way the Court talks about women wearing the face veil, and all forms of paternalism and 'othering' should be avoided.

\section{Concluding Remarks}

Procedural fairness is an important and useful concept for all types of situations in which individuals encounter the law. Its particular strength lies in its empirical basis in social psychology research, demonstrating the importance of procedural fairness for the legitimacy of legal authorities as well as for individual wellbeing. There are good reasons to state that procedural fairness merits particular attention in cases of minority justice. Moreover, it may be argued that best practice of procedural fairness is of particular importance when fundamental rights are at stake.

Our examination of the far-reaching procedural fairness flaws in the parliamentary and judicial treatment of the Belgian and French face veil bans has shown that disregard of procedural fairness makes for bad and harmful law. It is bad law, because it is not fit to address real problems: lack of

\footnotetext{
${ }^{149}$ http://www.oic-un.org/document report/Islamophobia rep May 2325 2009.pdf

150 Resolution 1743 (2010) Islam, Islamism and Islamophobia in Europe.

${ }^{151}$ Recommendation 1927 (2010) Islam, Islamism and Islamophobia in Europe, para. 3.13.

${ }^{152}$ See mutatis mutandis ECtHR, Koky and Others v. Slovakia, 12 June 2012, para. 239.

${ }^{153}$ See also Tulkens, Françoise, "The European Convention on Human Rights and Church-State Relations:

Pluralism vs. Pluralism”, Cardozo Law Review 30(6) (2009), p. 2587.
} 
Published in Journal of Muslims in Europe 2 (2013) 1-26

attention to participation, accuracy and neutrality have led to crucial errors in the identification of problems as well as remedies. It is moreover harmful law, because it results in stigmatization and violations of the very rights it proclaims to protect.

The European Court of Human Rights is well placed to lead the way toward procedural fairness as a necessary twin of substantive fairness in human rights adjudication. While the Court's case-law shows a number of instances in which it has violated crucial procedural fairness principles, it also shows a potential to play a role in both reviewing domestic procedural justice and leading through example. The upcoming face veil case of SAS v France will be an excellent opportunity for the Court to show both its willingness and its capacity to do so. 